\title{
IAMJ
}

INTERNATIONAL

AYURVEDIC

MEDICAL JOURNAL

Review Article

ISSN: 2320-5091

Impact Factor: 6.719

\section{STANDARDIZATION OF NASYA DOSE BY BINDU PRAMANA WITH KARPASASTYADI TAILA}

\section{$\underline{\text { Sreeja. V.S }}^{1}$, Vikram Kumar $^{2}$}

${ }^{1}$ Assistant Professor, Department of Panchakarma, Government Ayurveda college, Thiruvananthapuram, Kerala, India

${ }^{2}$ Associate Professor, Department of Panchakarma, Alvas Ayurveda Medical College, Karnataka, India

Corresponding Author: drsreejathottathil2@gmail.com

\section{https://doi.org/10.46607/iamj0709062021}

(Published Online: June 2021)

Open Access

(C) International Ayurvedic Medical Journal, India 2021

Article Received: 04/05/2021 - Peer Reviewed: 30/05/2021 - Accepted for Publication: 04/06/2021

\section{Check for updates}

\section{ABSTRACT}

Panchakarma therapy has a very important role in maintaining health of a person and eradication of diseases. The success with Panchakarma therapies can be achieved not only through correct assessment of the patient and the medicines used but also the dose of the medicine. Dose for this therapy is very specific and is explained in the classics on the basis of Bindu Pramana. Dose is a very important factor in any of the Panchakarma procedures to get optimum result of the therapy. Change in dose can change the result and further, it can lead to side effects or no effects. However, standardization of this dose had not been made yet. This paper deals with classical concept of Bindu Pramana, preparation, and standardization of Karpasastyadi Taila in Bindu Pramana Matra. The objective is to standardize the process of measurement of Bindu Pramana Matra of Karpasastyadi Taila. Healthy 60 individuals consisting of staffs and students of Alvas Ayurveda Medical College of either gender aged between 20 years to 60 years were selected and purposively assigned into study group. Results were observed and tabulation of data with a statistical commentary based on percentages of different observations was made. Study shows variation in quantity of Madhyama Bindu Pramana Matra and differs from patient to patient. Bindu Pramana varies from subject to subject. Analysis of the results showed that Bindu is not equivalent to drop.

Keywords: Panchakarma; Nasya Karma; Karpasastyadi Taila; Bindu Pramana 


\section{INTRODUCTION}

W.H.O defines drug as "A substance or product that is used or intended to be used to modify or explore physiological system or pathological status for the benefit of the recipient". The selection of a proper drug in the management of disease is very important and so of its dosage. In Ayurveda, the word Nasya has been taken specifically to mention the root of administration of the drugs. According to Acharya Sushruta ${ }^{1}$, administration of medicine or medicated oils through the nose is known as Nasya. Marsha and Pratimarsha both consist of instillation of oils through the nostrils. The method shared by both are common, but the variation occurs in the context of dose. In Pratimarsha Nasya 2 Bindus are administered while in Marsha Nasya the dose is of 6 to 10 Bindus. Ayurveda is having its own standards such as, Prasruta Pramana in case of Basti. Anguli Pramana for measurements of body parts, Anjali Pramana for measuring the quantity of body fluids etc. Similar way, Bindu is the unit of measurement defined for the Drava Dravya to be used in Nasya. The term Bindu was first coined by Susruta in the context of dose of Sneha Nasya ${ }^{2}$. Except Charaka all other Aacharyas used the word Bindu as the unit of measurement for any medicine in liquid form used for Nasya. Bindu is the unit of measurement and defined as the quantity of Drava (Sneha, Swarasa, Kashaya etc) that dribbles down when the first two parts of index finger are dipped into it and taken out ${ }^{3}$. Comment on this by Hemadri proves beyond doubt that not just the first drop is one Bindu, but it is the total quantity dribbling down from the index finger when immersed in the liquid should be considered as one Bindu

Concept of Bindu according to Sharangadhara Samhita: The dosage of Pratimarsha is two Bindu of oil, in each of the nostrils. Bindu is the quantity which falls at one stretch from the index finger after dipping it up to its two ridges and taken out. 8 such bindu are called 1 Sana $(2.5 \mathrm{ml})$ which is the dose of Marsha nasya ${ }^{4}$.

\section{Properties of Karpasastyadi Taila}

Taila is considered superior in treating Vata Dosha, as it possesses Ushna and Snigdha Gunas. Karpasasthyadi Taila $^{5}$ is indicated for Sarvanga Vata Vikara and has Vatahara and Brimhana action.

Table 1- Ingredients of Karpasastyadi Taila

\begin{tabular}{|l|l|l|l|l|}
\hline S1.No: & Drug & Latin name & Family & Part used \\
\hline 1. & Karpasasthi & Gossypium herbaceum & Malvaceae & Seed coat \\
\hline 2. & Bala & Sida cordifolia & Malvaceae & Root \\
\hline 3. & Masha & Phaseolus mungo & Leguminosae & Seed \\
\hline 4. & Kulattha & Dolichos biflorus & Fabaceae & Seed \\
\hline 5. & Devadaru & Cedrus deodara & Pinaceae & Bark, Heart wood \\
\hline 6. & Rasna & Pluchea lanceolate & Compositae & Leaves \\
\hline 7. & Nagara & Zingiber officinale & Zingiberaceae & Rhizome \\
\hline 8. & Kushta & Saussurea lappa & Compositae & Root \\
\hline 9. & Sarshapa & Brassica campestris & Cruciferae & Seed \\
\hline 10. & Shatapushpa & Anethum sowa & Umbelliferae & Fruit \\
\hline 11. & Chavya & Piper retrofractum & Piperaceae & Root, Fruit \\
\hline 12. & Shigru & Moringa oleifera & Moringaceae & Root bark \\
\hline 13. & Punarnava & Boerhavia diffusa & Nyctaginaceae & Root, Panchanga \\
\hline 14. & Tila Taila & Sesamum indicum & Pedaliaceae & Seed \\
\hline 15. & Aja Ksheera & Capra aegagrus-hircus & Bovidae & Milk \\
\hline
\end{tabular}


Table 2 - Pharmacodynamics of The Drugs In Karpasasthyadi Taila ${ }^{6,7}$

\begin{tabular}{|c|c|c|c|c|c|c|}
\hline Sl. No: & Name of drug & Rasa & Guna & Veerya & Vipaka & Karma \\
\hline 1 & Karpasasthi & Madhura & $\begin{array}{l}\text { Guru, } \\
\text { Snigdha }\end{array}$ & $\begin{array}{l}\text { Kinchit } \\
\text { Ushna }\end{array}$ & Madhura & $\begin{array}{l}\text { Vatapitashamak } \\
\text { Vedanasthapana }\end{array}$ \\
\hline 2. & Bala & Madhura & $\begin{array}{l}\text { Laghu, } \\
\text { Snigdha, } \\
\text { Picchila }\end{array}$ & Sheeta & Madhura & $\begin{array}{l}\text { Vedanasthapana } \\
\text { Vatashamaka, Shothahara, } \\
\text { Balya and Brimhana. }\end{array}$ \\
\hline 3. & Masha & Madhura & $\begin{array}{l}\text { Guru, } \\
\text { Snigdha }\end{array}$ & Ushna & Madhura & $\begin{array}{l}\text { Vedanasthapana } \\
\text { Vatashamaka, } \\
\text { Brimhana }\end{array}$ \\
\hline 4. & Kulattha & Kashaya & $\begin{array}{l}\text { Laghu, } \\
\text { Ruksha }\end{array}$ & Ushna & Katu & $\begin{array}{l}\text { Vedanasthapana } \\
\text { Vatashamaka, Svedajanaka. }\end{array}$ \\
\hline 5. & Devadaru & $\begin{array}{l}\text { Tikta, } \\
\text { Katu, } \\
\text { Kashaya }\end{array}$ & $\begin{array}{l}\text { Laghu, } \\
\text { Snigdha }\end{array}$ & Ushna & Katu & $\begin{array}{l}\text { Vedanasthapana } \\
\text { Vatashamaka, Balya, } \\
\text { Brimhana., Shothahara }\end{array}$ \\
\hline 6. & Rasna & Tikta & Guru & Ushna & Katu & $\begin{array}{l}\text { Vataharam, Vedanasthapana } \\
\text { Shothahara, Sheetahara. }\end{array}$ \\
\hline 7. & Nagara & Katu & $\begin{array}{l}\text { Laghu, } \\
\text { Snigdha }\end{array}$ & Ushna & Madhura & $\begin{array}{l}\text { Vedanasthapana } \\
\text { Vatashamaka, Shothahara, } \\
\text { Sheeta Prashamana. }\end{array}$ \\
\hline 8. & Kushta & $\begin{array}{l}\text { Tikta, } \\
\text { Katu, } \\
\text { Madhura }\end{array}$ & $\begin{array}{l}\text { Laghu, } \\
\text { Ruksha, } \\
\text { Tikshna }\end{array}$ & Ushna & Katu & $\begin{array}{l}\text { Vedanasthapana } \\
\text { Vatashamaka and } \\
\text { Svedajanaka. }\end{array}$ \\
\hline 9. & Sarshapa & $\begin{array}{l}\text { Katu } \\
\text { Tikta }\end{array}$ & $\begin{array}{l}\text { Laghu } \\
\text { Snigdha }\end{array}$ & Ushna & Katu & $\begin{array}{l}\text { Snehana, } \quad \text { Shula } \\
\text { Prashamana, Balya }\end{array}$ \\
\hline 10. & Shatapushpa & $\begin{array}{l}\text { Katu } \\
\text { Tikta }\end{array}$ & $\begin{array}{l}\text { Laghu } \\
\text { Ruksha } \\
\text { Tikshna }\end{array}$ & Ushna & Katu & $\begin{array}{l}\text { Vedanasthapana } \\
\text { Shothahara, Svedajanaka }\end{array}$ \\
\hline 11. & Chavya & Katu & $\begin{array}{l}\text { Laghu } \\
\text { Ruksha }\end{array}$ & Ushna & Katu & $\begin{array}{l}\text { Shula Prashamana } \\
\text { Kapha Vata-Shamaka }\end{array}$ \\
\hline 12. & Shigru & $\begin{array}{l}\text { Katu } \\
\text { Tikta }\end{array}$ & $\begin{array}{l}\text { Laghu } \\
\text { Ruksha } \\
\text { Tikshna }\end{array}$ & Ushna & Katu & $\begin{array}{l}\text { Vata-Kaphahara } \\
\text { Shula-Prashamana, } \\
\text { Shothahara, Svedajanaka }\end{array}$ \\
\hline 13. & Punarnava & $\begin{array}{l}\text { Madhura } \\
\text { Tikta } \\
\text { Kashaya }\end{array}$ & $\begin{array}{l}\text { Laghu } \\
\text { Ruksha }\end{array}$ & Ushna & Madhura & $\begin{array}{l}\text { Tridosha shamana } \\
\text { Shothahara and Svedopaga }\end{array}$ \\
\hline 14. & Tila Taila & $\begin{array}{l}\text { Madhura } \\
\text { Kashaya }\end{array}$ & $\begin{array}{l}\text { Guru } \\
\text { Snigdha } \\
\text { Vyavayi }\end{array}$ & Ushna & Madhura & $\begin{array}{l}\text { Kapha-Vata Shamaka, } \\
\text { Snehana, Vedanasthapana, } \\
\text { Twachya and Balya, } \\
\text { Yogavahi }\end{array}$ \\
\hline 15. & Aja Ksheera & $\begin{array}{l}\text { Madhura } \\
\text { Kashaya }\end{array}$ & $\begin{array}{l}\text { Laghu, } \\
\text { Snigdha } \\
\text { Mridu }\end{array}$ & Sheeta & Madhura & $\begin{array}{l}\text { Vata-Pitta Shamaka } \\
\text { Balya and Sarva Vyadhihara }\end{array}$ \\
\hline
\end{tabular}


Table 3: Chemical constituents of the drugs in Karpasastyadi Taila

\begin{tabular}{|l|l|l|}
\hline Sl.No: & Name of Drug & Chemical constituents \\
\hline 1 & Karpasasthi & Gossypol Caryophyllene, Pinene, Limonene. \\
\hline 2. & Bala & Ephedrine, Hypaphorine, Vasicinone, Choline, Betaine, Phytosterol \\
\hline 3. & Masha & Albuminoid, Starch and Fibre \\
\hline 4. & Kulattha & Genistein, Dalbergioidin, Phasecollidin \\
\hline 5. & Devadaru & Deodarin, Toxifolin Atlantone Etc \\
\hline 6. & Rasna & Galangin, Kaempferide, Diaryl Heptanoids \\
\hline 7. & Kushta & Gingerone, Ginger Glycolipids A, B \&C, Paradol, D Curcumene \\
\hline 8. & Shatapusha $a$ & Sitosterol, Dehydro Costuhactone. \\
\hline 9. & Chavya & Sinalbin, Rutin, - Arabinogalactan. \\
\hline 10. & Shigru & $\begin{array}{l}\text { Piperine, Sitosterol, Piplartine, } \\
\text { Retrofractamidea, B, C\&D }\end{array}$ \\
\hline 11. & Punarnava & Moringine, Sterols, Terpenes \\
\hline 12. & Tila Taila & $\begin{array}{l}\text { Beta-Sitosterol, Oxalicacid, Dglucose } \\
\text { Punarnavoside, Hentriacontane Etc }\end{array}$ \\
\hline 13. & Aja Ksheera & Neutral-Lipids, Glycolipids\& Phospholipids, Sesamose, Sesamolin Etc. \\
\hline 14. & Amino acids, Fatty Acids, Lactose Etc \\
\hline 15. &
\end{tabular}

By considering the pharmacological properties of all the 15 known drugs it may be said that the combination may be having Madhura Kashaya Rasa; Snigdha, Laghu, Tikshna and Vyavayi Guna; Ushna Veerya; Madura Vipaka; Kapha Vata Shamaka properties with the specific actions like Vedanasthapana, Shothahara, Svedajanaka, Balya and Brimhana.

\section{METHODOLOGY}

\section{Preparation of medicine}

Kashaya was prepared by adding 32 litres of water reduced to 4 litres after adding the Kashaya Dravya. Moorchita Tila Taila was prepared. To this, Kashaya was added and boiled over mild fire. The Kalka Dravya are prepared by making a paste and added to the oil. Aja Ksheera is added to the boiling oil and stirred thoroughly over mild fire till the Paka Siddhi Lakshanas are obtained. Then cooled and filtered into airtight container and stored

Table 4: Quantity of drugs taken for preparation of Karpasastyadi Taila:

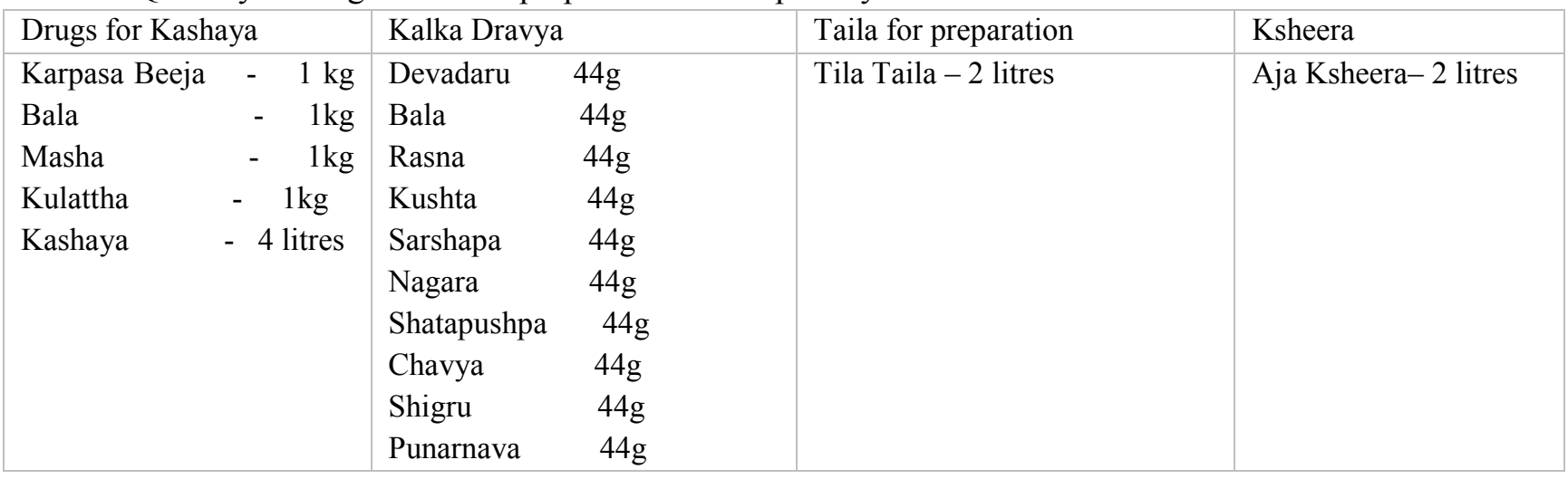


Assessment of the quantity of one Bindu of Karpasasthyadi Taila: A study was conducted to fix the dose of Karpasasthyadi Taila in 60 samples to assess the quantity of one Bindu of oil between age group of 20-60 years, irrespective of sex, height, weight and dimensions of index finger. Participants were asked to dip the first two parts of the right index finger (Phalanges) in Karpasasthyadi Taila, then was taken out and the total quantity which was drippling down were considered as one Bindu for that participant.

\section{Result:}

Table 5: Quantity of one Bindu of Karpasastyadi Taila as per the study

\begin{tabular}{|l|l|l|l|}
\hline Sample size & Mean Bindu in $\mathrm{ml}$ & SD & SE \\
\hline 60 & 0.45 & 0.09353 & 0.01708 \\
\hline
\end{tabular}

It was observed that mean Bindu is $0.45 \mathrm{ml}+\ldots 0.093 \mathrm{ml}$ and SE of $0.017 \mathrm{ml}$.

\section{DISCUSSION}

The age group of 20-60yrs was selected, is to compromise a non-contraindicated age group for Marsha Nasya category. In 60 participants most of them got variables like $0.4 \mathrm{ml}, 0.5 \mathrm{ml}, 0.35 \mathrm{ml}, 0.45 \mathrm{ml}$ etc. Variables observed ranged in between $0.35 \mathrm{ml}$ and $0.5 \mathrm{ml}$. Difference in variable found may be due to variation in right index finger size of the participants. From the study it was observed while doing the standardisation of Bindu Pramana for Nasya karma with Karpasastyadi Taila, one Bindu is $0.45 \mathrm{ml}$. The Madhyama Matra of Marsha Nasya is 8 Bindu. So Nasya dosage with Karpasastyadi Taila in Madyama Matra is $3.6 \mathrm{ml}$.

\section{CONCLUSION}

For research works in Ayurveda to get global acceptance, it is essential to standardise the dosage of medicines that we use in Panchakarma therapies. As ayurvedic classics describe on Bindu Pramana for Nasya dosage, there is a need to convert and standardise the dosage in daily life standards which will have a universal acceptance. From the current study it is concluded that, dosage for Nasya karma with Karpasastyadi Taila, one Bindu is equal to $0.45 \mathrm{ml}$. in age group 20-60yrs. This dose can be considered as standard dose for further studies.

\section{REFERENCES}

1. Susruta, Susrutha Samhitha with Nibandhasangraha commentary of Dalhanacharya and Nyayachandrika Panjika of Sri Gayadasacharya, edited by Vaidya Jadavji
Trikamji Acharya, Chaukamba Sanskrit Sansthan, Reprint- 2008, Chikitsa Sthana 40/21-29; Pp: 554-555

2. Susruta, Susrutha Samhitha with Nibandhasangraha commentary of Dalhanacharya and Nyayachandrika Panjika of Sri Gayadasacharya, edited by Vaidya Jadavji Trikamji Acharya, Chaukamba Sanskrit Sansthan, Reprint- 2008, Chikitsa Sthana 40/28; Pp: 556

3. Vagbhata-Ashtanga Hrdaya with Sarvanga Sundara Arunadatha Commentry and Ayurvedarasayana Hemadri Commentry Edited by Pt. Hari Sandiva Sastri Paradakara Bhisagacarya, Chaukhambha Surbharati Prakashan Varanasi, Reprinted in 2007.Sutrasthana 20/9; Pp: 289

4. Sharangadharacarya: Sharangadhara Samhita, with text, English translation; translated by Prof. K.R.Srikantha Murthy, Reprint edition, 2009, published by Chaukhambha Sanskrit series office, Varanasi. Ut 8/3840: Pp:227

5. Dr.K.Nishteshwar and Dr. R. Vidyanath-Sahasrayogam, Chaukamba Sanskrit Series, Varanasi, 2nd Edition, 2008, Taila Prakarana. Pp:.118

6. J.L. N Shastry Illustrated Dravyaguna Vinjana part -2, edited by J.L.N.Sastry, published by Chaukhamba Orientalia, Varanasi;Reprint Edition - 2012; Pp:87, $139,258,307,507,574,630,821$

7. Prof.P.V.Sharma; Dravyaguna Vijnana-Vol-2,published by Chaukhambha bharati academy,Varanasi;reprint2001; Pp:513

\section{Source of Support: Nil \\ Conflict of Interest: None Declared}

How to cite this URL: Sreeja. V. S \& Vikram Kumar: Standardization Of Nasya Dose By Bindu Pramana With Karpasastyadi Taila. International Ayurvedic Medical Journal \{online\} 2021 \{cited June, 2021\} Available from: http://www.iamj.in/posts/images/upload/1200_1204.pdf 